\title{
High-Resolution Land Use and Land Cover Mapping
}

\section{Background}

As the Nation's population grows, quantifying, monitoring, and managing land use becomes increasingly important. The U.S. Geological Survey (USGS) has a long heritage of leadership and innovation in land use and land cover (LULC) mapping that has been the model both nationally and internationally for over 20 years. At present, the USGS is producing high-resolution LULC data for several watershed and urban areas within the United States. This highresolution LULC mapping is part of an ongoing USGS Land Cover Characterization Program (LCCP). The four components of the LCCP are global $(1: 2,000,000-$ scale), national (1:100,000-scale), urban (1:24,000-scale), and special projects (various scales and time periods). Within the urban and special project components, the USGS Rocky Mountain Mapping Center (RMMC) is collecting historical as well as contemporary high-resolution LULC data. RMMC's high-resolution LULC mapping builds on the heritage and success of previous USGS LULC programs and provides LULC information to meet user requirements.

\section{Applications}

The demand for large-scale LULC information has increased recently, especially in rapidly growing metropolitan areas. Many Federal, State, regional, and local planning agencies require up-to-date LULC information for various applications. These applications include modeling urban growth (fig. 1), determining land suitability for future development, monitoring how land use changes affect the environment, understanding land use patterns, and developing zoning policies concerning land use development.

\section{Characteristics of High-Resolution LULC}

The USGS requirements for collecting highresolution LULC features include a minimum mapping unit between 2.5 and 5 acres and a minimum polygon width of 125 feet. The identification of LULC categories follows a modified Anderson classification system (Anderson 1976) developed by the RMMC (fig 2 and 3). Currently, the USGS is mapping LULC features down to level 6 of the hierarchal classification system, which contains over 75 categories. Some of the LULC categories collected include urban parks, natural grasslands, major retail, light industry, and row crops. Typically, the LULC features are collected using 1-meter resolution digital orthophoto quadrangles. Ancillary data sources, such as aerial photographs, USGS 1:24,000-scale quadrangles, and information derived in the field, are used to help enhance the interpretation and classification of the land surface features. The LULC data are compiled by 1:24,000scale quadrangles using USGS-developed software and are later merged to form a seamless data set for each project area. Reading Reference: Anderson, James; Hardy, Ernest; Roach, John; and Witmer, Richard, 1976, A Land Use and Land Cover Classification System for Use with Remote Sensor Data: U.S. Government Printing Office, Washington, D.C.

\section{Guiding Principles}

- Compatible with current and past USGS programs, such as the MultiResolution Land Characterization and Land Use Data Programs.

- Built on partnerships

- Flexible, based on user's needs

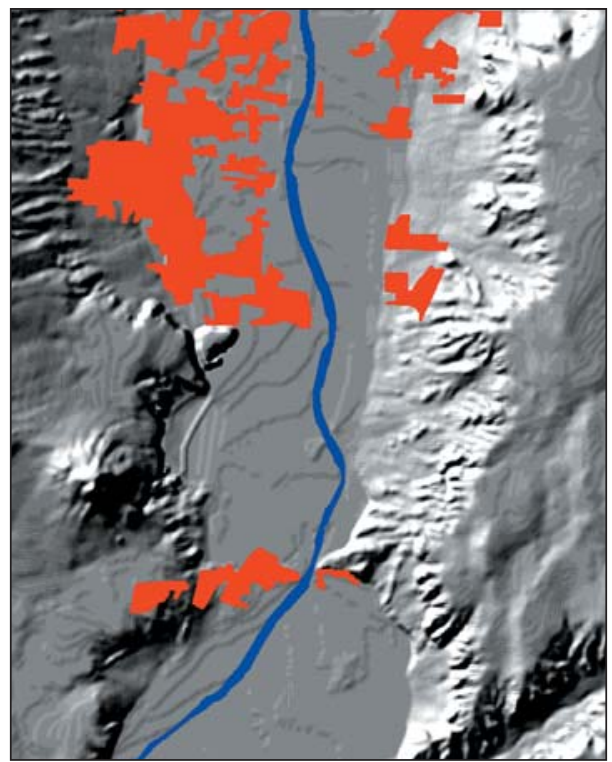

Figure 1: A shaded relief representation of Modeling urban growth in the Albuquerque, N. Mex. Area. The area on the left shows superimposed red polygons derived from 1996 urban area land use land cover data. The area on the right shows the same area with predicted 2050 urban growth.

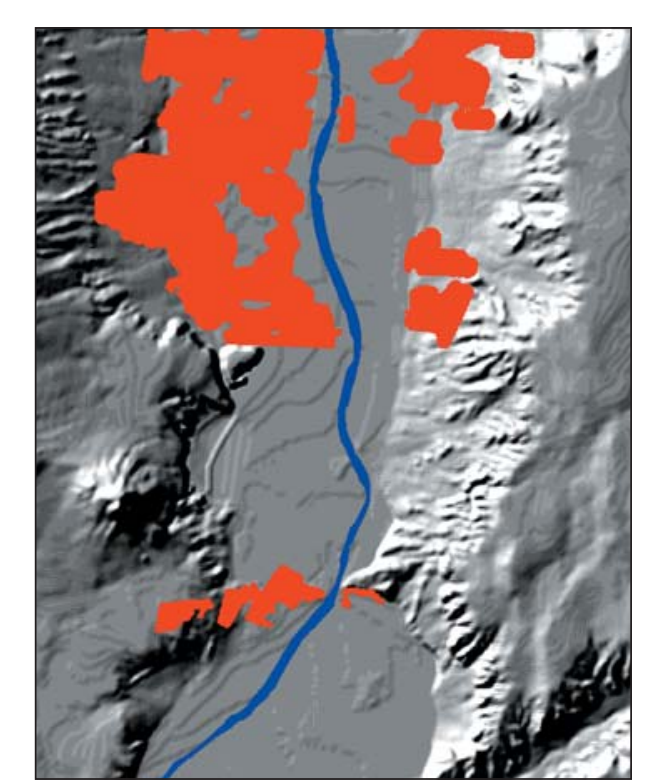

For information specific to USGS highresolution LULC mapping, contact: HRLC Program Manager P.O. Box 25046, MS 509 Denver, CO 80225-0046 or

USGS Mapping Liaisons mapping.usgs.gov/www/partners/ crreps.html.

For information on these and other USGS products and services, call 1-888-ASKUSGS, use the Ask.USGS fax service, which is available 24 hours a day at 703648-4888, or visit the general interest publications Web site on mapping, geography, and related topics at mac.usgs.gov /mac/isb/pubs/pubslists/index.html.

For additional information, visit the ask.usgs.gov Web site or the USGS home page at www.usgs.gov.

\section{Current Projects:}

Middle Rio Grande Basin Study: rockyweb.cr.usgs.gov/mrgb/ lulc_over.html.

Front Range Infrastructure Resources Project: rockyweb.cr.usgs.gov/frontrange. 
Fort Logan, Colorado, 1997 Land Use and Land Cover

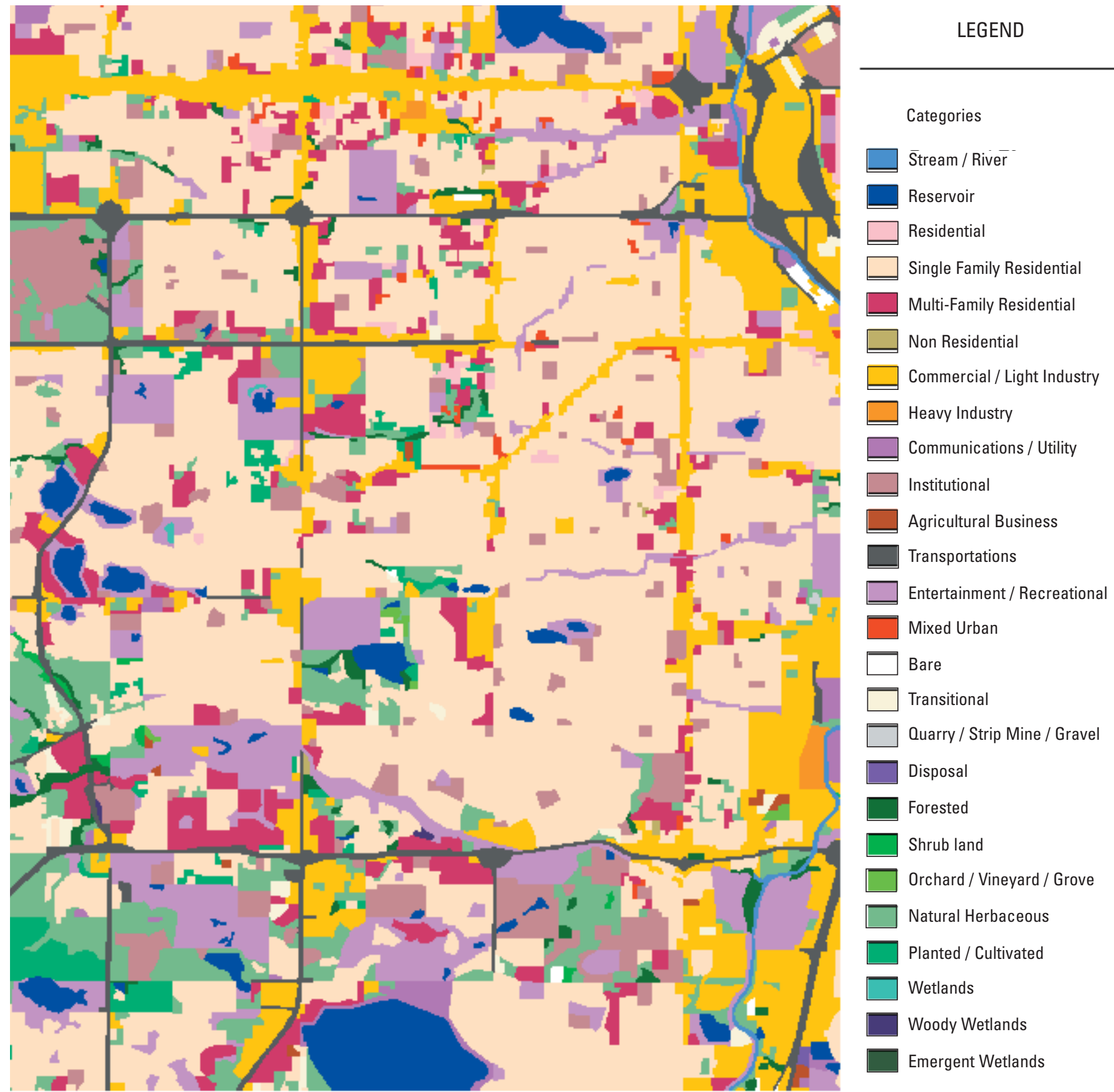

Figure 2. A USGS 1:24,000-scale quadrangle showing the land surface area categorized on the basis of the modified Anderson classification system.

\begin{tabular}{|c|c|c|c|}
\hline Level 1 & Level 2 & Level 3 & Level 4 \\
\hline \multirow[t]{8}{*}{2.0 Developed } & \multirow[t]{2}{*}{ 2.1 Residential } & 2.11 Single-Family Residential & \\
\hline & & 2.12 Multifamily Residential & \\
\hline & \multirow[t]{5}{*}{ 2.2 Nonresidential Developed } & \multirow[t]{4}{*}{ 2.21 Commercial/Light Industry } & 2.211 Major Retail \\
\hline & & & \begin{tabular}{|l}
$2.212 \begin{array}{l}\text { Mixed/Minor Retail and } \\
\text { Services }\end{array}$ \\
\end{tabular} \\
\hline & & & 2.213 Office \\
\hline & & & 2.214 Light Industry \\
\hline & & 2.22 Heavy Industrial & 2.221 Petrochemical Refinery \\
\hline & 2.3 Mixed Urban & & \\
\hline
\end{tabular}

Figure 3. The "developed" land use category and subcategories from the modified Anderson classification system. 